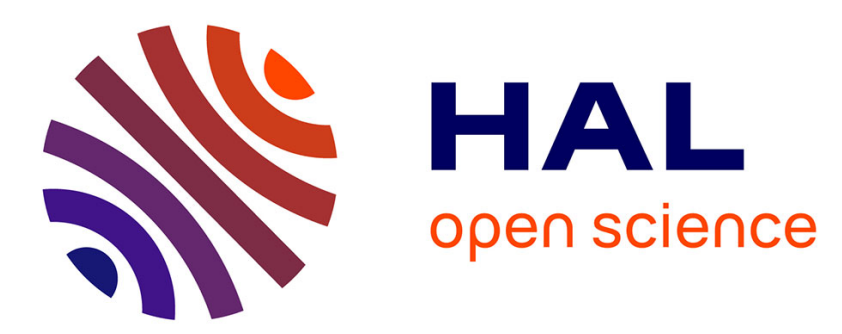

\title{
Effects of fecal age and seasonality on steroid hormone concentration as a reproductive parameter in field studies
}

\author{
Teresa Abáigar, Miguel A. Domené, Francisco Palomares
}

\section{- To cite this version:}

Teresa Abáigar, Miguel A. Domené, Francisco Palomares. Effects of fecal age and seasonality on steroid hormone concentration as a reproductive parameter in field studies. European Journal of Wildlife Research, 2010, 56 (5), pp.781-787. 10.1007/s10344-010-0375-z . hal-00580177

\section{HAL Id: hal-00580177 \\ https://hal.science/hal-00580177}

Submitted on 27 Mar 2011

HAL is a multi-disciplinary open access archive for the deposit and dissemination of scientific research documents, whether they are published or not. The documents may come from teaching and research institutions in France or abroad, or from public or private research centers.
L'archive ouverte pluridisciplinaire HAL, est destinée au dépôt et à la diffusion de documents scientifiques de niveau recherche, publiés ou non, émanant des établissements d'enseignement et de recherche français ou étrangers, des laboratoires publics ou privés. 


\title{
Effects of fecal age and seasonality on steroid hormone concentration as a reproductive parameter in field studies
}

\author{
Teresa Abáigar • Miguel A. Domené • \\ Francisco Palomares
}

Received: 17 November 2009/Revised: 1 March 2010 / Accepted: 5 March 2010/Published online: 27 March 2010

(C) Springer-Verlag 2010

\begin{abstract}
We studied how fecal age (6, 12, 24, 48, 72, and $168 \mathrm{~h}$ ) and seasonality affect variation in the fecal steroid hormone metabolite concentration in three endangered mammalian species, Mhorr gazelle, Saharan Barbary sheep, and the Iberian lynx. Except for estrogens, concentrations remained stable for at least $48 \mathrm{~h}$ in the Mhorr gazelle and the Saharan Barbary sheep. Steroid hormone metabolite concentration remained stable in the Iberian lynx throughout the experiment (1 week). Seasonality was the main factor affecting variation in hormone metabolite concentrations, and although the response was species- and hormone-specific, the dry season resulted in increased hormone metabolite concentrations, while the wet season reduced the concentration.
\end{abstract}

Keywords Ammotragus lervia $\cdot$ Fecal steroids · Gazella dama mhorr $\cdot$ Hormone degradation $\cdot$ Lynx pardinus

\section{Introduction}

Noninvasive fecal steroid metabolite analysis has been widely developed and used over the last 20 years, and

Communicated by C. Gortázar

T. Abáigar $(\square) \cdot$ M. A. Domené

Estación Experimental de Zonas Aridas/CSIC,

Crta. De Sacramento s/n,

04120-La Cañada de S. Urbano,

Almería, Spain

e-mail: abaigar@eeza.csic.es

F. Palomares

Department of Conservation Biology, Estación Biológica de

Doñana/CSIC, Avda. Américo Vespucio s/n,

Isla de la Cartuja,

41092 Sevilla, Spain longitudinal data series on reproductive status and welfare of captive, semi-captive, and free-ranging wildlife species have been collected (reviewed in Schwarzenberger 2007). However, the accuracy of such analyses may be affected by fecal sampling and storage (Khan et al. 2002; Schwarzenberger 2007; Herring and Gawlik 2009), particularly for free-ranging species, as locating fresh feces daily may often not be possible or be inappropriate due to behavioral restrictions (Linklater et al. 2000). Frequently, the only fecal material available has been exposed to different environmental/weather conditions for an unknown length of time.

Because of microbial metabolism and other biochemical processes that occur over time, changes in humidity and temperature are probably the most influential environmental factors affecting steroid metabolite concentration in feces of free-ranging animals (Washburn and Millspaugh 2002; Terio et al. 2002). Moreover, under field conditions, the fecal material undergoes changes in water content derived from its exposure to changing seasonal environmental conditions. To avoid bias derived from changing water content, most studies analyzing fecal steroids use feces that have been lyophilized before analysis and report the steroid concentrations as nanograms per gram dry feces. However, fresh, wet fecal samples are used increasingly (see Pickard et al. 2001; Schoenecker et al. 2004; Monclús et al. 2009; Pelican et al. 2009). Although the dilutive effect of water content on fecal steroid metabolites has been proven (Monclús et al. 2009), it has not been demonstrated that bias in results from wet fecal samples not collected daily is due exclusively to water content, or to the microbiological and biochemical processes during the time elapsed until sampling, or a combination of both.

The purpose of this study was to determine the effects of seasonality on the final concentrations of steroid hormones 
(estrogens, testosterone, and progestagen metabolites) in fresh feces exposed to field conditions for different periods of time in order to determine whether fecal material collected in the field can be used for accurate steroid hormone metabolite analysis.

The study was carried out using captive individuals of three endangered mammalian species: one carnivore, the Iberian lynx (Lynx pardinus), and two herbivores, the Mhorr gazelle (Gazella dama mhorr) and the Saharan Barbary sheep (Ammotragus lervia sahariensis). Two different groups of mammals were used to test the effect of climatic conditions on different types of fecal material since hormone degradation is expected to be related to fecal composition.

\section{Materials and methods}

\section{Study areas}

Mhorr gazelle (MG) and Saharan Barbary sheep (SBS) were maintained in captivity in the Parque de Rescate de la Fauna Sahariana (Estación Experimental de Zonas Àridas) in Almería $\left(36^{\circ} 45^{\prime} \mathrm{N}, 3^{\circ} 00^{\prime} \mathrm{W}\right)$ on the Mediterranean coast of southeastern Spain, one of the warmest and most arid areas in Europe. The mean annual temperature is $18^{\circ} \mathrm{C}$ and the average rainfall is $237 \mathrm{~mm}$ (Lázaro et al. 2001). The Iberian lynx (IL) was kept in the "El Acebuche" breeding center at Doñana National Park, which is close to the Atlantic coast in southwestern Spain $\left(36^{\circ} 56^{\prime} \mathrm{N}, 6^{\circ} 21^{\prime} \mathrm{W}\right)$. Owing to its proximity to the Mediterranean Sea, the climatological regime is Mediterranean with Atlantic influences, the mean annual temperature is $18^{\circ} \mathrm{C}$, and the average rainfall is $<600 \mathrm{~mm}$ (Yánez et al. 2006).

\section{Source of animals}

Feces were collected from captive adults of all three species which were living in outdoor conditions under captive breeding programs implemented to prevent their extinction and support reintroduction into their original habitats (see Alados et al. 1988; Alados and Vericad 1993; Barbosa and Espeso 2005; http://www.lynxexsitu.es for more details). Captive IL were fed live domestic rabbits daily, MG and SBS were fed commercial pellets, barley, and fresh alfalfa, and SBS also received a daily ration of straw. Water was always available ad libitum for all three species.

\section{Experimental design}

Early in the morning, feces from ten adult male and ten adult female MG and SBS were individually collected immediately after voidance; samples were collected off the floor but avoiding those directly in contact with the soil surface. After collection, 12 individual droppings from each MG and eight individual droppings from each SBS were weighed and then stored at $-20^{\circ} \mathrm{C}$ until analysis. The rest of the droppings, previously homogenized, were placed directly on soil and exposed to environmental conditions inside a small open-air enclosure to avoid disturbance. The same number (12 for MG and 8 for SBS) were then taken from these previously collected droppings at $6,12,24,48$, 72 , and $168 \mathrm{~h}$ after voidance, weighed and stored at $-20^{\circ} \mathrm{C}$. To test for the effect of different climatic conditions, this sampling procedure was repeated seasonally (spring: April 11-15, 2005; summer: July 4-8, 2005; autumn: November 28 to December 2 2005; winter: February 16-26, 2006). In addition, after a winter rainfall event, additional samples were taken $96 \mathrm{~h}$ after voidance to test the effect of a complete event of wetting-drying.

Once each season (spring: May 17-24, 2006; summer: August 22-28; autumn: December 13-20, 2006; winter: March 14-21, 2007), fresh feces were also collected early in the morning from 11 adult female and six adult male IL. The fecal material collected in the morning was from depositions left the night before, and the precise time between the deposition/voidance and fecal collection could not be known exactly, but was always $<10 \mathrm{~h}$. To account for possible heterogeneous distribution of the steroid hormones in a single fecal bolus, each was subdivided into five sections, and a small portion of each section was immediately frozen until analysis. We thus ensured that differences in hormone concentration within feces did not affect the results. The remaining fecal material was placed directly on soil and exposed to the prevailing environmental conditions in a protected open-air enclosure and samples of each portion were taken and frozen until analysis at 12, 24, 48,72 , and $168 \mathrm{~h}$ from collection.

Temperature and relative humidity were recorded at 5min intervals throughout the study using a micrologger (HOBOC, ONSET Computer Corporation, USA) placed $10 \mathrm{~cm}$ above the soil. Table 1 shows average temperatures, rainfall, and humidity during the study.

\section{Steroid extraction and assay}

Steroid hormone metabolites (progestagens, estrogens, and testosterone) in all fecal samples were extracted and determined following standardized procedures. Steroids were extracted by following a standardized protocol (Brown et al. 1994) with minor modifications. Briefly, fecal material was mixed thoroughly and a subsample of $0.18-0.2 \mathrm{~g}$ was extracted using ethanol $(100 \%, 4.5 \mathrm{~mL})$ and distilled water $(0.5 \mathrm{~mL})$; after $30 \mathrm{~min}$ of shaking (Multipulse vortexer, Glas-Col ${ }^{\circledR}$, USA), samples were centrifuged at $1,076 \times g$ for $20 \mathrm{~min}$, the supernatant was transferred to a 
Table 1 Temperature $\left(T,{ }^{\circ} \mathrm{C}\right)$, humidity $(H, \%)$, and rainfall $(\mathrm{mm}$, mean, range) in the study areas, Almería and Doñana National Park (Spain)

\begin{tabular}{|c|c|c|c|c|c|c|}
\hline & \multicolumn{3}{|l|}{ Almería } & \multicolumn{3}{|l|}{ Doñana N.P. } \\
\hline & $T$ & $H$ & $R$ & $T$ & $H$ & $R$ \\
\hline Spring & $15.5(6.3-24.3)$ & $68.9(33.4-98.4)$ & 0 & $23.2(8.2-34.4)$ & $53.8(12.7-98.7)$ & 0 \\
\hline Summer & $28.9(21.6-40.6)$ & $53.6(12.3-88.2)$ & $0.2(0-1.0)$ & $26.5(10.6-40.6)$ & $30.75(12.4-46.5)$ & 0 \\
\hline Autumn & $12.2(4.5-19.6)$ & $55.1(20.3-94.2)$ & 0 & $7.8(1.9-15.0)$ & $85.3(73.2-99.9)$ & 0 \\
\hline Winter & $12.8(6.2-19.1)$ & $77.9(51.0-94.6)$ & $0.82(0-7.4)$ & $12.9(5.2-20.1)$ & $70.1(36.0-96.4)$ & 0 \\
\hline
\end{tabular}

glass tube, and the pellet resuspended in $4.5 \mathrm{~mL}$ of ethanol and $0.5 \mathrm{~mL}$ of distilled water, vortexed (1 $\mathrm{min})$, and recentrifuged. Combined supernatants were then dried and evaporated with dry air. One milliliter of methanol was added to the dry extract and placed in an ultrasonic glass cleaner (Branson ${ }^{\circledR} 8510$ ) for $20 \mathrm{~min}$. The extracts were diluted in a dilution buffer and stored frozen until analysis.

Fecal steroid hormone metabolites were determined following the procedures described by Munro et al. (1991) for enzyme immunoassay. Antibodies for progestin (monoclonal Pregnane CL425, 1:10,000 dilution), estrogen (polyclonal $\mathrm{E}_{2}-\mathrm{R} 4972$, 1:10,000 dilution), and testosterone (polyclonal testosterone R-156/7, 1:7,500 dilutions) were provided by Coralie Munro (University of California, Davis, CA, USA). The CL425 cross-reacts with various progestagen metabolites, including 4-pregnen-3,20-dione (100\%), 4-pregnen-3 $\alpha$-ol-20-one (188\%), 4-pregnen-3 $\beta$-ol20-one (172\%), 4-pregnen-11 $\alpha$-ol-3,20-dione (147\%), $5 \alpha$ pregnan-3 $\beta$-ol-20-one (94\%), $5 \alpha$-pregnan-3 $\beta, 20$-dione

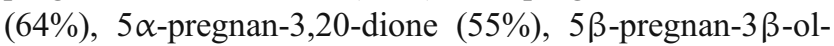
20-one $(12.5 \%)$, 5-pregnan-3,20-dione (8.0\%), 4-pregnen$11 \beta$-ol-3,20-dione (2.7\%), and 5 $\beta$-pregnan-3 $\alpha$-ol-20-one (2.5\%; Graham et al. 2001). The R4972 cross-reacts with estradiol 17B (100\%) and estrone (3.3\%). The R156/7 cross-reacts with testosterone $(100 \%)$ and $5 \alpha-$ dihydrotestosterone (57.37\%). Before analysis, fecal extracts were diluted in phosphate-buffered saline (MG: $1: 10$ to $1: 50$ for estrogens, $1: 50$ to $1: 3,000$ for progestagens, and $1: 10$ to $1: 20$ for testosterone; SBS: $1: 10$ to $1: 20$ for estrogens, 1:50 to $1: 600$ for progestagens, and 1:10 to $1: 20$ for testosterone; IL: 1:5 to 1:540 for estrogens, 1:50 to $1: 4,800$ progestagens, and 1:10 to $1: 40$ for testosterone). Serial dilutions of pooled fecal extracts produced displacement curves parallel to those of the appropriate standard. The correlation coefficients of parallelism test were $R^{2}=0.985, R^{2}=0.983, R^{2}=0.992$ for progestagens, estrogens, and testosterone, respectively. Inter-assay CVs were $($ mean \pm SEM) 7.98 $\pm 2.04,8.25 \pm 1.1$, and $8.46 \pm 1.29$ for progestagens, estrogens, and testosterone, respectively; intra-assay $\mathrm{CVs}$ were $<10 \%$. Assay sensitivities were $1.17 \mathrm{pg} /$ well (estrogens), $1.09 \mathrm{pg} /$ well (progestagens), and $2.05 \mathrm{pg} /$ well (testosterone). Absorbance was measured at
$405 \mathrm{~nm}$ with an automatic microtiter plate spectrophotometer $\left(\right.$ Tecan $^{\circledR}$, sunrise, Austria), and the data were transferred to an interfaced computer (Magellan ${ }^{\circledR}$, Austria). Hormone concentrations are expressed as nanograms per gram wet feces, except for IL progestagens which is expressed as micrograms per gram wet feces.

Data analysis

General linear models (type III for MG and SBS and type $\mathrm{V}$ for IL) were used to test the effect of fecal age and season on steroid metabolite concentration. Multiple comparisons (Bonferroni test) were used to determine significant differences in feces of different ages and seasons.

The change in hormone metabolite concentration was expressed as the percent difference between the original hormone metabolite concentration $\left(C_{t 0}\right)$ and the concentration at the later sampling time $\left(C_{t \mathrm{i}}\right)$. Thus, much of the variation in hormone metabolite concentration was eliminated by the reproductive cycle of the individual involved. The individual was treated as a random effect in the analysis. A negative value means lower hormone metabolite concentration than at the starting time $\left(C_{t 0}\right)$. Fecal weight was also included as a variable in the analysis. This might be important since hormone metabolite concentration was expressed by wet fecal weight and might therefore be influenced by variation in temperature and humidity across seasons. This variable was expressed as the percentage difference between the original weight $\left(t_{0}\right)$ and weight at the later sampling time $\left(t_{\mathrm{i}}\right)$.

As IL feces were subdivided into five sections to test for unequal hormone distribution within the same feces, we used a repeated measure ANOVA to test for uniform distribution of steroid hormone metabolites in individual fecal samples. At time 0, no significant differences were found either for all steroid metabolites together $(F=1.69$, $d f=4, p=0.279$ ) or for each individual steroid metabolites $(F=1.28, d f=8, p=0.251)$; therefore, the average of the five sections at time 0 (control) was taken to calculate the variation in steroid hormone metabolite concentrations at the different sampling times. 
Statistical analyses were performed with STATISTICA for Windows (Statsoft UK, Letchworth).

\section{Results}

Variation in fecal hormone metabolite concentrations in the two herbivores largely depends on the time of exposure to field conditions and season (Table 2). The seasonal effect on variation in $M G$ progestagens was only significant when tested as an individual effect (ANOVA $F=4.6, d f=3, p=$ 0.004 ), while variation in the IL fecal steroid metabolites concentration was only significant as a function of season (Table 2). Moreover, variation in MG and SBS fecal estrogen concentration showed a weak but significant correlation with variation in fecal weight (MG: $F=4.4$, $d f=1, p=0.04, r=0.14$; SBS: $F=7.2, d f=1, p=0.007, r=$ 0.18 ). Variation in estrogen concentration decreases as fecal weight rises as a result of hydratation after a winter rainfall event.

In the two herbivores, most variation in fecal steroid metabolite concentration was found in testosterone and progestagens, followed by the estrogens. In the IL, variation in the three hormone metabolites was quite similar between themselves, although slightly higher in testosterone.

MG progestagen and testosterone concentrations remained stable for the first $48 \mathrm{~h}$, but became significantly higher after $72 \mathrm{~h}$ with increases in summer and winter (Table 3). Seasonal effects on variation in testosterone concentration were significant in summer when concentrations were highest at 72 and $168 \mathrm{~h}$ after voidance and in winter at 12 and $24 \mathrm{~h}$ when they were lowest (Table 3 ). The percentage variation in estrogen concentration in MG was significantly increased $12 \mathrm{~h}$ after voidance in summer when concentrations are highest and was lowest in winter 12 and $24 \mathrm{~h}$ after voidance (Table 3).

With the exception of the SBS samples during winter, the percent variation of progestagens remained stable throughout exposure. Nevertheless, there were significant differences between seasons; in winter, the values showed little change over the first $24 \mathrm{~h}$ of exposure, while in summer, the values were more stable after the first $24 \mathrm{~h}$ (Table 3). Testosterone concentrations remained stable for $48 \mathrm{~h}$, with the least variation in autumn and winter. After that, a significant increase was observed at $72 \mathrm{~h}$ in autumn and at $168 \mathrm{~h}$ in winter (Table 3). The percentage variation in estrogens varied with exposure time, with the least variation recorded in summer after $24 \mathrm{~h}$ of exposur, and was also significantly low in autumn after $6 \mathrm{~h}$ of exposure and in winter after the first $6 \mathrm{~h}$ of exposure (Table 3 ). In the $\mathrm{IL}$, significant seasonal differences were observed with the least variation in hormone concentration in autumn and winter (Table 3).

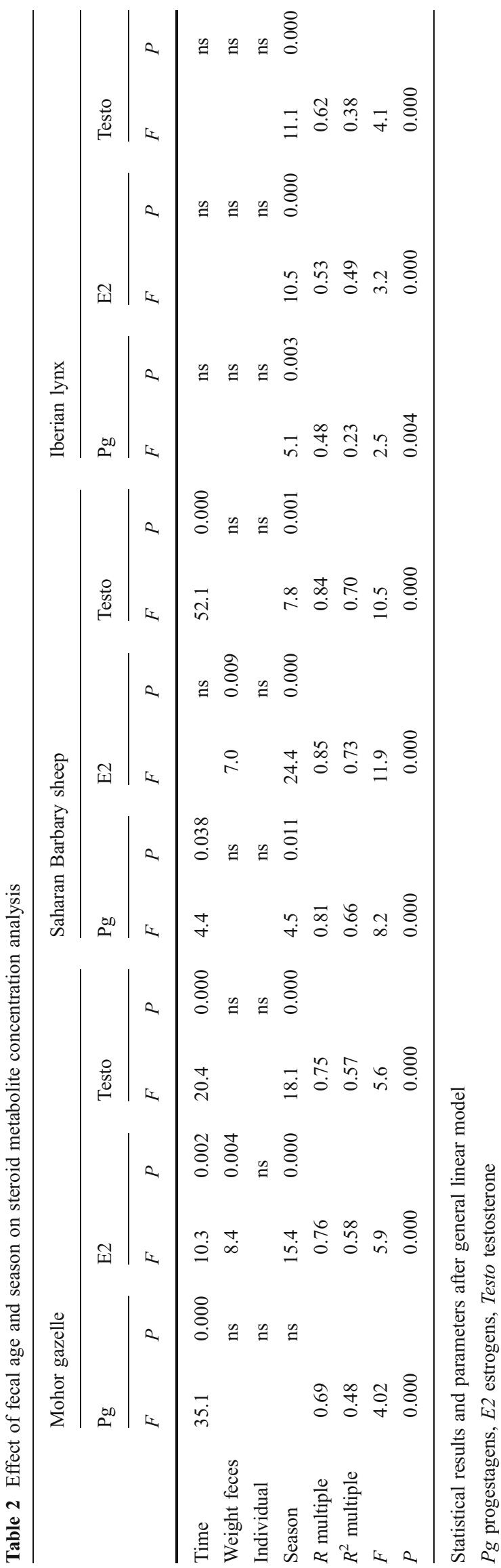




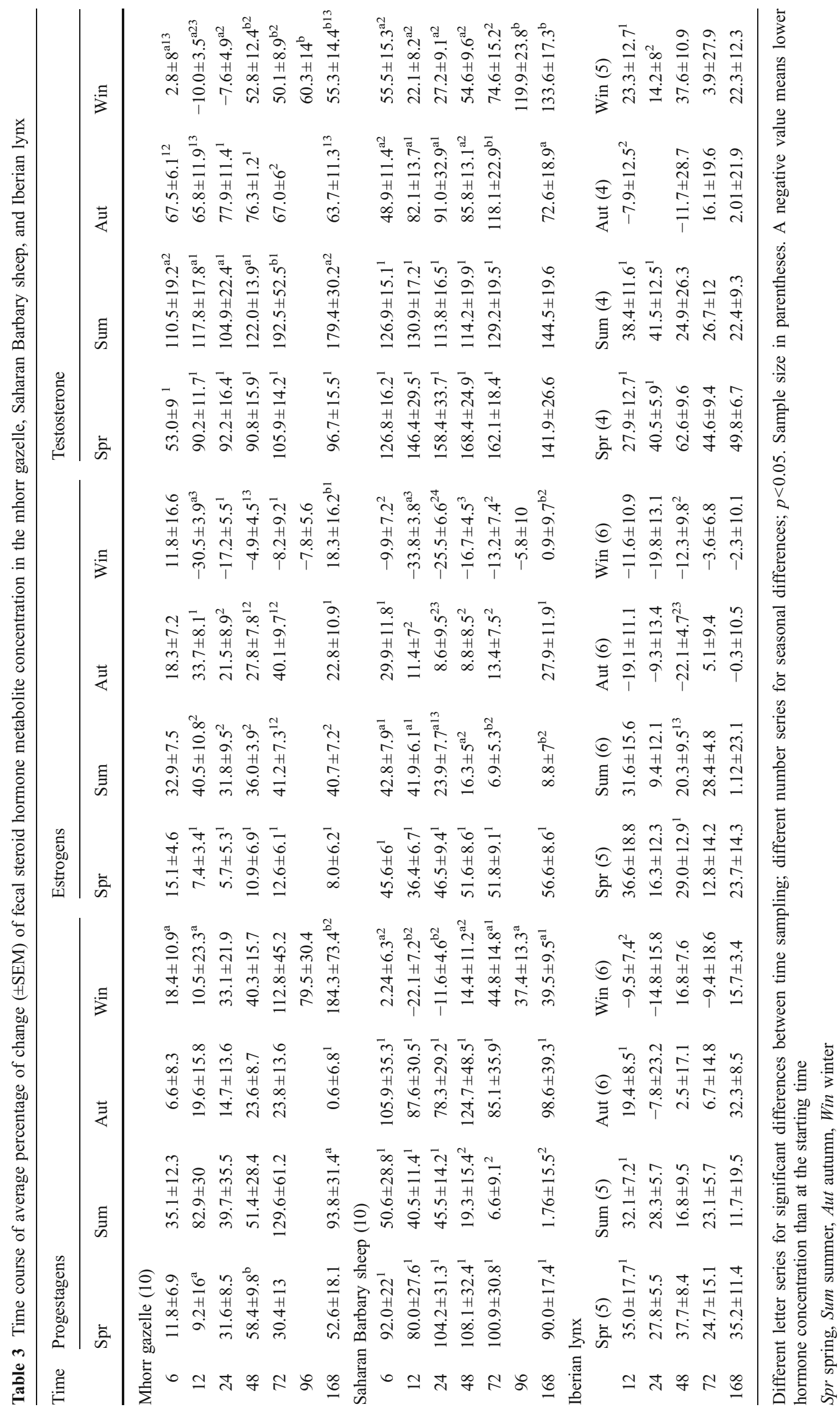




\section{Discussion}

Variation in progestagens and testosterone concentrations of the two herbivore species studied remained stable for at least $48 \mathrm{~h}$ after voidance (168 $\mathrm{h}$ for SBS progestagens). However, changes in estrogen concentrations were significant after $6 \mathrm{~h}$ of exposure. In the IL, hormone metabolite concentrations remained stable throughout the experiment (1 week). Consequently, if the purpose of a field study is qualitative definition of reproductive events, old fecal samples ( $48 \mathrm{~h}$ after voidance for SBS and MG and 1 week for IL) can be used, unless the study requires estrogen determination (only up to $6 \mathrm{~h}$ in MG and SBS feces). However, caution is needed if the study requires hormone determinations for major reproductive events (e.g., onset of puberty, ovulation) to be accurate as the variations in hormone concentration from the fresh feces were very high for all three species and the three hormone metabolites (especially testosterone metabolites in the two herbivore species). This means that in terms of a field study, feces age fast. These results are in agreement with the findings of Millspaugh and Washburn (2004) who recommended the collection of only fresh samples $(<1$ or $2 \mathrm{~h}$ old $)$.

Variation in fecal weight following exposure of feces to field conditions only had a significant effect on variation in SBS and MG estrogen concentration. This hormone was sensitive to the diluting effect of the winter rainfall event in Almeria. Differences in diet between the two herbivores (MG and SBS) and the carnivore (IL) are likely to be among the causes of these species-specific differences. The higher fiber content in herbivore feces explains their ability to retain (by hydrating) or to eliminate (by drying) water, and these results might therefore only reflect a difference in the water content of the feces. Although this study did not show a significant effect of fecal weight on the other hormones or species studied, we suspect that it could potentially affect feces sampled after a rainfall event. The majority of the negative or small variations in concentration in these three MG and SBS hormones were found in winter and in the IL in autumn and winter during the first $48 \mathrm{~h}$ of the experiment related to rainfall events in the study areas at that time. Consequently, collection of fecal material immediately after a rainfall event or in a humiditysaturated atmosphere is not recommended.

These results further support species-specific differences in steroid metabolism (Schwarzenberger 2007). The origin of all these differences is the confluence of multiple causes pointed out by other authors: specificity of microbes in the feces that metabolize the fecal steroids, effect of temperature on steroid metabolite degradation, environmental moisture which allows the growth of microbes and fungi, change in metabolite affinity for antibodies, and the different chemical stability of each hormone (Matkovics
1972; Woods 1975; Neumann et al. 2002; Terio et al. 2002; Washburn and Millspaugh 2002; Millspaugh and Washburn 2004). Exhaustive condition-controlled laboratory metabolism studies, followed by precise identification of new metabolites, HPLC mass spectrometry, nuclear magnetic resonance, or infrared spectroscopy, are recommended to find out the precise hormone metabolism and degradation processes and the factors affecting them. These results would permit the development and use of more specific antibodies for precise results when degraded fecal samples are used to study reproductive processes under field conditions.

As a general conclusion, this study shows that the use of fecal samples of unknown age to monitor reproduction in animals under field conditions is of limited use. Although it is suitable for the qualitative determination of reproductive events, it is not as successful for accurate determination of hormone concentrations. Aged fecal samples should not be collected in summer because hormone degradation is likely to change the resultant measurements. Moreover, fecal samples collected in a humid atmosphere or after a rainfall event should be desiccated to avoid errors deriving from fecal water content.

Acknowledgments We thank the Parque de Rescate de la Fauna Sahariana (Estación Experimental de Zonas Áridas, Almería) and the Centro de Cría del Lince Ibérico "El Acebuche" (Parque Nacional de Doñana, Huelva) for access to the animals and logistical support. We also thank Ch. Petronella, A. López, J. Cassinello, and J.C. Rivilla for field assistance. W.V. Holt and two anonymous reviewers made useful comments of this manuscript. This work was funded by the Spanish Ministry of Education and Research (grant CGL2004-00603) and the European Regional Development Fund.

\section{References}

Alados CL, Vericad JR (1993) Aoudad. Ammotragus lervia from Western Sahara. International Studbook. Boletin de Estudios Almerienses. Ciencias 11(12):65-97

Alados CL, Escós J, Vericad JR (1988) Captive populations of Northwest African antilopinae and caprinae at the Estación Experimental de Zonas Áridas. In: Dixon A, Jones D (eds) Conservation and biology of desert antelopes. Christopher Helm Ltd., Kent, pp 199-211

Barbosa A, Espeso G (2005) Internacional studbook. Gazella dama mhorr. CSIC, Madrid, $128 \mathrm{pp}$

Brown JL, Wasser SK, Wildt DE, Graham LH (1994) Comparative aspects of steroid hormone metabolism and ovarian activity in felid measured non-invasively in feces. Biol Reprod 51:776-786

Graham L, Schwarzenberger F, Möstl E, Galama W, Savage AA (2001) A versatile enzyme immunoassay for the determination of progestogens in feces and serum. Zoo Biol 20:227-236

Herring G, Gawlik DE (2009) Stability of avian fecal corticosterone metabolite levels in frozen avian feces. J Wildlife Manage 73:1010-1013

Khan MZ, Altmann I, Isani SS, Yu J (2002) A matter of time: evaluating the storage of fecal samples for steroid analysis. Gen Comp Endocr 128:57-64 
Lázaro T, Rodrigo FS, Gutiérrez L, Domingo F, Puigdefábregas J (2001) Analysis of a 30-year rainfall record (1967-1997) in semiarid SE Spain for implications on vegetation. J Arid Environ 48:373-395

Linklater W, Henderson KM, Cameron EZ, Stattford KJ, Minot EO (2000) The robustness of faecal steroid determination for pregnancy testing Kaimanawa feral mares under field conditions. New Zeal Vet J 48:93-98

Matkovics B (1972) In vitro transformation of steroids as a substitute of microbial transformation. Steroids Lipids Res 3:1-7

Millspaugh JJ, Washburn BE (2004) Use of fecal glucocorticoid metabolite measures in conservation biology research: considerations for application and interpretation. Gen Comp Endocr 1238:189-199

Monclús R, Palomares F, Tablado Z, Martínez-Fontúrbel A, Palme R (2009) Testing the threat-sensitive predator avoidance hypothesis: physiological responses and predator pressure in wild rabbits. Oecologia 158:615-623

Munro CJ, Stabenfeldt GH, Cragun JR, Addiego LA, Overstreet JW, Lasley BL (1991) Relationship of serum estradiol and progesterone concentrations to the excretion profiles of their major urinary metabolites as measured by enzyme immunoassay and radioimmunoassy. Clin Chem 37(6):838-844

Neumann G, Gottschalk J, Eulenberger K, Grün E (2002) Studies on the stability of progestagens in faeces of several wild animal species kept in a zoological garden. Dtsch Tierärztl Wschr 109:245-249

Pelican K, Abáigar T, Vargas A, Rodríguez JM, Bergara J, Rivas A, Martinez F, Rodríguez D, Brown J, Wildt DE (2009) Hormone profiles in the iberian lynx: application to "in situ" and "ex situ" conservation. In: Vargas A, Breitenmoser C, Breitenmoser U (eds) Iberian Lynx Exsitu Conservation: an interdisciplinary approach. Fundación Biodiversidad, Madrid, pp 358-368

Pickard AR, Abaigar T, Green DI, Holt WV, Cano M (2001) Hormonal characterization of the reproductive cycle and pregnancy in the female mohor gazelle (Gazella dama mhorr). Reproduction 122:571-580

Schoenecker KA, Lyda RO, Kirkpatrick J (2004) Comparison of three fecal steroid metabolites for pregnancy detection used with single sampling in bighorn sheep (Ovis canadiensis). J Wildlife Dis $40: 273-281$

Schwarzenberger F (2007) The many uses of non-invasive faecal steroid monitoring in zoo and wildlife species. Int Zoo Yearb 41:52-74

Terio KA, Brown JL, Moreland R, Munson L (2002) Comparison of different drying and storage methods on quantifiable concentration of fecal steroids in the cheetah. Zoo Biol 21:215-222

Washburn BE, Millspaugh JL (2002) Effects of simulated environmental conditions on glucocorticoid metabolite measurements in white-tailed deer feces. Gen Comp Endocr 127:217-222

Woods GF (1975) Chemical and microbiological transformation of steroids. In: Cameron EHD, Hillier SG, Griffiths K (eds) Steroid inmunassays. Alpha Omega, Cardiff, pp 5-10

Yánez C, Rodríguez Ramírez A, Carrión García JS (2006) Cambios en la vegetación de la franja litoral de las marismas de Doñana (Huelva, España) durante el holoceno reciente. Ana Biol 28: $85-94$ 